\title{
New locations and parasitological findings for the invasive shrimp Palaemon macrodactylus in temperate southwestern Atlantic coastal waters
}

\author{
Sergio R. Martorelli, Pilar Alda, Paula Marcotegui, Martín M. Montes, \\ Luciano F. La Sala
}

Centro de Estudios Parasitológicos y Vectores (CEPAVE), CCT-La Plata 2 Nro. 584, La Plata 1900, Argentina

\begin{abstract}
This paper presents new records that considerably expand the geographical range of the invasive shrimp Palaemon macrodactylus in Argentina to include new estuarine areas on the Argentine south Atlantic coast: Bahía Samborombón, and the Bahía Blanca and Río Negro estuaries. The latter 2 locations are the southernmost reports for this species. The epibiotic barnacle Balanus amphitrite and a microphallid metacercaria Odhneria sp. are reported for the first time in P. macrodactylus. The prevalence of white spot syndrome virus (WSSV) was $10 \%$ in the Bahía Blanca estuary. Our results strongly suggest that WSSV is spreading in crustacean populations in the Argentine Sea and that P. macrodactylus plays a role in the ecology of parasite infections in this environment.
\end{abstract}

KEY WORDS: Oriental shrimp · Palaemon macrodactylus $\cdot$ Parasites $\cdot$ Barnacles $\cdot$ Microphallidae · White spot syndrome virus · Argentina

\section{INTRODUCTION}

The oriental shrimp Palaemon macrodactylus Rathbun, 1902, is an invasive crustacean in Argentina that has been widely dispersed outside of its native range in the coasts of Japan, Korea, and northern China (Rathbun 1902, Newman 1963, Spivak et al. 2006). The species was first reported in Argentina in the Mar del Plata harbor by Spivak et al. (2006). Although there have not been any new reports of P. macrodactylus in Argentina since then, it was postulated that the species has a great potential to move beyond natural dispersal barriers and to become established and prolific (González-Ortegón et al. 2007). Moreover, Spivak et al. (2006) suggested the Mar del Plata port as an entrance site and possible dispersion center for $P$. macrodactylus.

Among others, the 'enemy release' hypothesis posits that in their native range, populations are regulated by enemies, but these enemies are re- duced in number or absent from populations outside their natural dispersal range, thereby allowing introduced species to escape regulatory forces and become invasive (Hierro et al. 2005). Recent research has recognized the role of parasites (both macro- and microparasites) as such enemies and has documented lower numbers of parasites occurring in invasive host species in invaded, compared to natural, ranges (Torchin et al. 2001, Torchin \& Mitchell 2004). Consequently, the study of the parasites present in an invasive species in a new environment is an important first step to better understanding the factors that favor or impede successful biological invasions.

The objectives of the present study were 2-fold: (1) to assess the expansion of Palaemon macrodactylus in areas outside its known distributional range in Argentina, and (2) to investigate the presence of helminths, white spot syndrome virus (WSSV), and epibionts in this invasive shrimp. 


\section{MATERIALS AND METHODS}

Shrimp were sampled between March 2007 and March 2011 at 4 sites in Argentina: the Río Salado flood relief channel (Site 1: $35^{\circ} 50^{\prime} \mathrm{S}, 57^{\circ} 25^{\prime} \mathrm{W} ; \mathrm{n}=$ 49) and Tapera de López (Site 2: $36^{\circ} 19^{\prime} \mathrm{S}, 56^{\circ} 46^{\prime} \mathrm{W}$; $\mathrm{n}=46$ ) in Bahía Samborombón, the Bahía Blanca estuary (Site 3: $38^{\circ} 44^{\prime} \mathrm{S}, 62^{\circ} 22^{\prime} \mathrm{W} ; \mathrm{n}=110$ ), and the Río Negro estuary (Site $4: 41^{\circ} 1^{\prime} \mathrm{S}, 62^{\circ} 47^{\prime} \mathrm{W} ; \mathrm{n}=1$ ). The first 3 sites are located in the Buenos Aires province, and the fourth site is in the Río Negro province (Fig. 1). Specimens were collected using cast nets and minnow traps baited with fish meat. The specimens were transported alive to the laboratory and kept in small aquaria with seawater. Some ovigerous females were kept alive until their eggs hatched, and the resulting larvae were fixed in $10 \%$ formalin for morphological studies.

The shrimp were studied alive, killed by freezing, and fixed in $10 \%$ formalin until examination for parasites using a stereomicroscope. A total of 20 specimens from Bahía Blanca estuary were examined fresh for the presence of white spots suggestive of WSSV. These specimens were then preserved in $96 \%$ ethanol and tested for WSSV using nested PCR. DNA was extracted from the gills using DNeasy kits (Quiagen). PCR amplification was conducted using illustra PuReTaq Ready-To-Go ${ }^{\mathrm{TM}}$ PCR Beads (GE Healthcare). Details of the primers and PCR procedures used are described by Martorelli et al. (2010). Unless otherwise stated, throughout the present study, we refer to parasites and pathogens as simply 'parasites'.

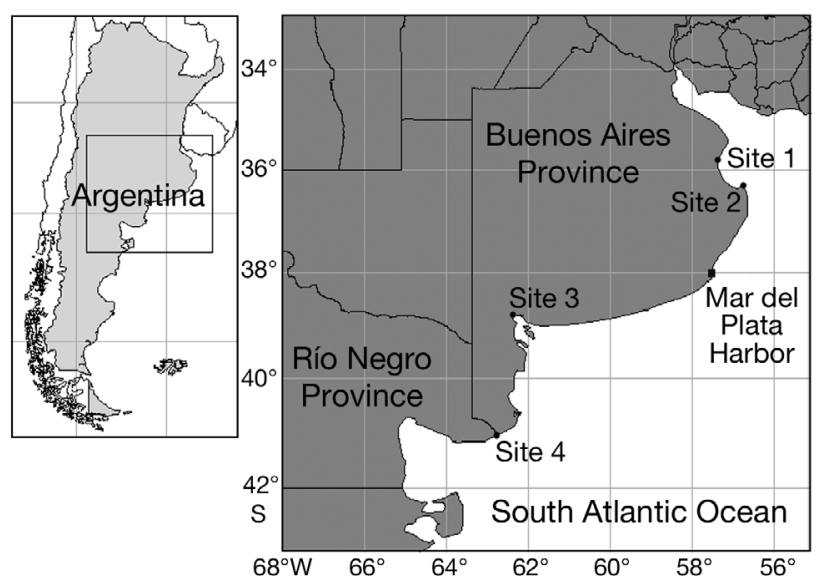

Fig. 1. Palaemon macrodactylus sample sites. Site 1: Río Salado flood relief channel. Site 2: Tapera de López. Site 3: Bahía Blanca estuary. Site 4: Río Negro estuary. Mar del Plata Port: first reported site of $P$. macrodactylus in Argentina
We deposited voucher specimens from each sampling area in the invertebrate collection of the La Plata Museum (voucher number): Río Salado (26753) and Tapera de López in Bahía Samborombón (26754), Bahía Blanca estuary (26755), and Río Negro estuary (26756). We also deposited one specimen with an epibiont from Tapera de López (26757) and zoea larvae from Bahía Blanca estuary (26758).

\section{RESULTS}

The present paper presents the southernmost report of Palaemon macrodactylus off the southwestern Atlantic coast. We also report for the first time a helminth parasite and an epibiotic exotic crustacean in $P$. macrodactylus and provide new data on the prevalence of WSSV in P. macrodactylus from the Argentine Sea. P. macrodactylus individuals, including females bearing eggs with viable embryos, were found at all of the study sites (Fig. 1).

Three types of biological interactions - with helminths, epibionts, and one virus - were identified in Palaemon macrodactylus. Among the helminths, a digenean metacercaria (Microphallidae) was found encysted in the cephalothorax of one specimen (Table 1) and was tentatively identified as Odhneria sp. (Fig. 2). Among the epibionts, the barnacle Balanus amphitrite Darwin, 1854, was found on the exoskeleton of shrimps (Table 1, Fig. 3). Some individuals had melanized cuticular lesions (Table 1, Fig. 4). A total of $25 \%$ (5 of 20) of P. macrodactylus from the Bahía Blanca estuary that were examined fresh had WSSV-like cuticular spots. The spots measured 1 to $3 \mathrm{~mm}$ in diameter. Also, 10\% (2 of 20) of the specimens tested through PCR were positive for WSSV, but only one $(0.05 \%)$ of these had white spots on fresh examination (Table 1, Fig. 5).

\section{DISCUSSION}

In Argentina, Palaemon macrodactylus has been previously reported only in the Mar del Plata port (Spivak et al. 2006). To date, that first report and the one in Lake Mannering in Australia (Buckworth 1979) were the 2 most southern records for the species. Therefore, this work greatly expands the current distributional range of the species along the Argentine Atlantic coast and represents the southernmost record for this species. The new locations reported here indicate the great capacity of the species to adapt to a range of environments around the world 
Table 1. Prevalence of conditions investigated in Palaemon macrodactylus in Argentina. F: ovigerous females; M: males; WSSV: white spot syndrome virus; na: not applicable; ne: not examined; $95 \%$ CI: $95 \%$ confidence interval for prevalence. See Fig. 1 for site locations and description. Water temperatures from the National Hydrographic Service (www.hidro.gov.ar)

\begin{tabular}{|c|c|c|c|c|c|c|c|}
\hline \multirow[t]{2}{*}{ Site } & \multirow{2}{*}{$\begin{array}{c}\text { Water temp. } \\
\text { (annual range, } \\
{ }^{\circ} \mathrm{C} \text { ) }\end{array}$} & \multirow{2}{*}{$\begin{array}{l}\text { Sample } \\
\text { size }\end{array}$} & \multirow{2}{*}{$\begin{array}{l}\text { Carapace length } \\
\text { (range, mm) }\end{array}$} & \multicolumn{4}{|c|}{ - Prevalence (\%) and $95 \% \mathrm{CI}$} \\
\hline & & & & Odhneria sp. & $\begin{array}{l}\text { Balanus } \\
\text { amphitrite }\end{array}$ & $\begin{array}{c}\text { Melanized } \\
\text { cuticular lesions }\end{array}$ & WSSV \\
\hline 1 & $13-23$ & $\begin{array}{l}\text { F: } 65 \\
\text { M: } 29\end{array}$ & $\begin{array}{l}12-16 \\
21-26\end{array}$ & 0 & $6.4(2.7-13.5)$ & $6.4(2.7-13.5)$ & ne \\
\hline 2 & $11-23$ & $\begin{array}{l}\mathrm{F}: 30 \\
\mathrm{M}: 16\end{array}$ & $\begin{array}{l}14-17 \\
18-24\end{array}$ & 0 & $8.7(2.9-20.9)$ & $15.2(7.3-28.5)$ & ne \\
\hline 3 & $4-23$ & $\begin{array}{l}\text { F: } 80 \\
\text { M: } 30\end{array}$ & $\begin{array}{l}16-29 \\
12-16\end{array}$ & $0.9(\sim 0.0-5.5)$ & 0 & $1.8(\sim 0.0-6.8)$ & $10.0(1.6-31.3)$ \\
\hline 4 & $4-24$ & $\begin{array}{l}\mathrm{F}: 1 \\
\mathrm{M}: 0\end{array}$ & $\begin{array}{l}19 \\
\text { na }\end{array}$ & 0 & 0 & 0 & ne \\
\hline
\end{tabular}

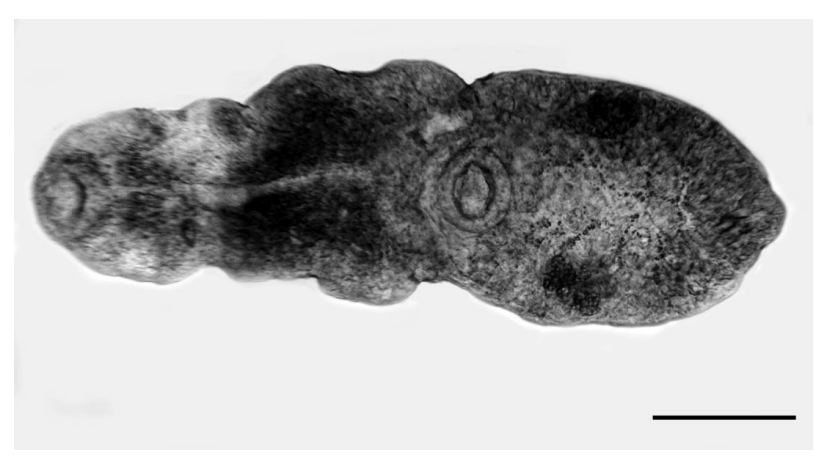

Fig. 2. Odhneria sp. Experimental unencysted metacercariae. Scale bar $=0.15 \mathrm{~mm}$

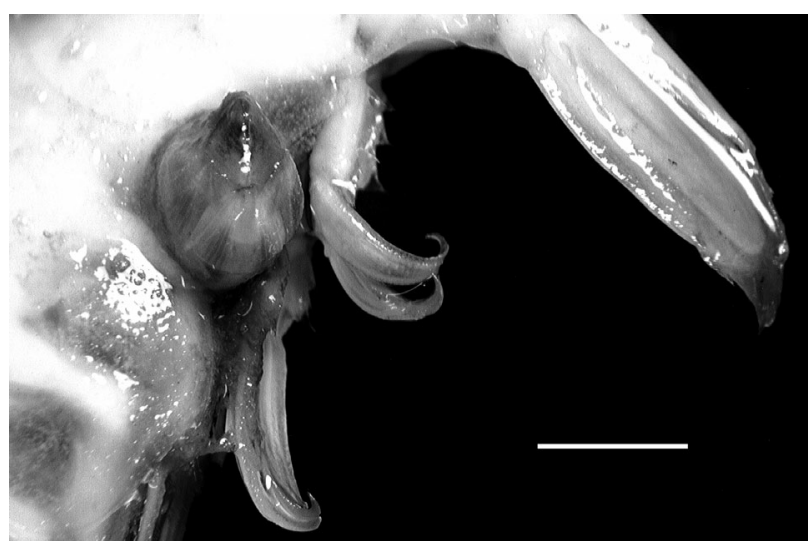

Fig. 3. Barnacle Balanus amphitrite fixed in the tail region of Palaemon macrodactylus from Bahía Samborombón. Scale bar $=2 \mathrm{~mm}$

and confirm early predictions that $P$. macrodactylus would rapidly expand in Argentina (Spivak et al. 2006).

Palaemon macrodactylus may have been introduced in the Mar del Plata harbor from the Pacific via discharged ballast water (Wasson et al. 2001). As Spivak et al. (2006) predicted, larvae may have been dis-

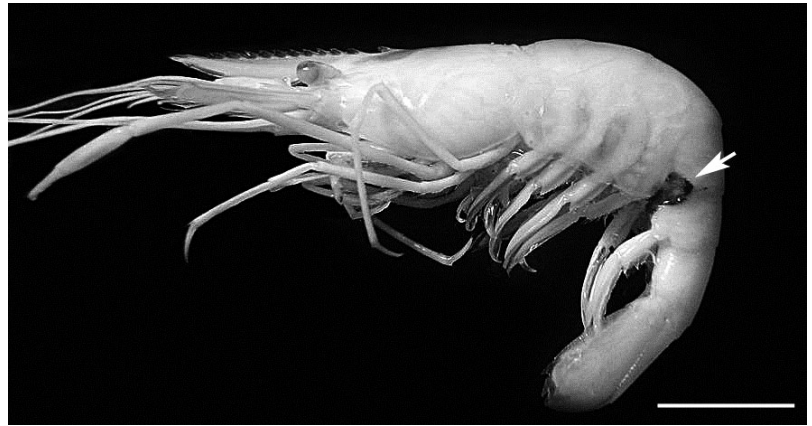

Fig. 4. Melanized cuticular lesions in posterior abdominal region of Palaemon macrodactylus (arrow). Scale bar $=10 \mathrm{~mm}$

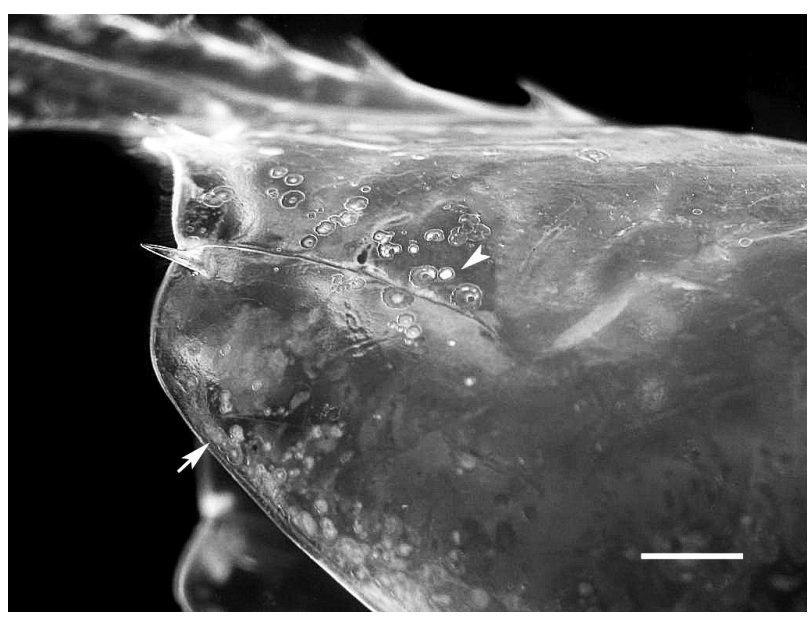

Fig. 5. White spot on surface of the cephalothorax from a WSSV-positive Palaemon macrodactylus (arrows). Scale bar $=1.5 \mathrm{~mm}$

persed both north and south of the initial entrance point and then colonized brackish water habitats.

The main diagnostic morphological characteristics of the studied specimens agreed with those reported by Rathbun (1902), Newman (1963), d'Udekem d'A- 


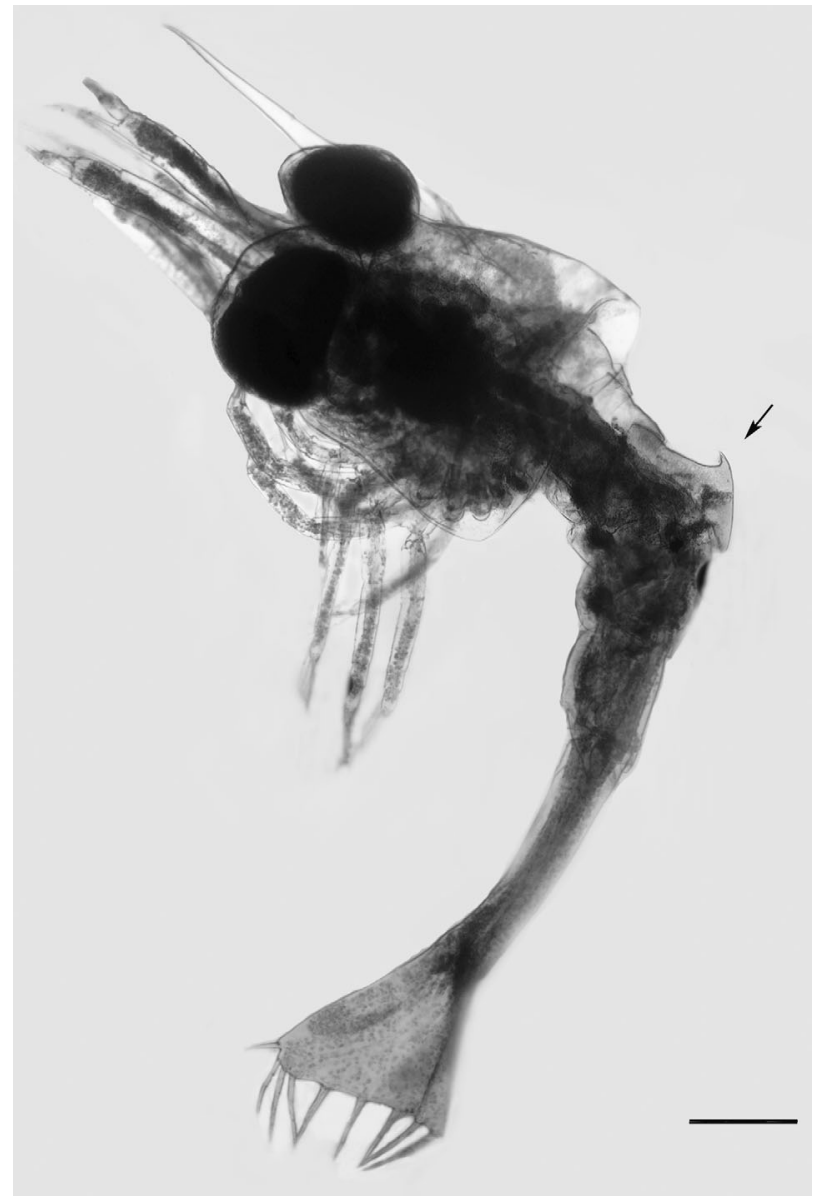

Fig. 6. Two-day-old laboratory-reared zoea of Palaemon macrodactylus. Arrow: hook-shaped dorsal spine. Scale bar $=$ $0.2 \mathrm{~mm}$

coz et al. (2005), González-Ortegón \& Cuesta (2006), and Elder \& Fuller (2012). The carapace of the ovigerous females collected in the Bahía Blanca and Bahía Samborombón estuaries was longer than that reported by Spivak et al. (2006) for females in Mar del Plata (12-29 mm vs. $16.5-19 \mathrm{~mm}$ ). Live specimens of Palaemon macrodactylus showed a whitish longitudinal dorsal stripe similar to that reported by d'Udekem d'Acoz et al. (2005). Laboratory-reared zoea also showed the typical hook-shaped dorsal spine in the third abdominal segment (Fig. 6) (González-Ortegón \& Cuesta 2006).

The digenean metacercaria reported here was remarkably similar to that of Odhneria sp. reported by Alda et al. (2011). A heteroxenic life cycle, like the one described for the genus Odhneria (Stunkard 1979), makes it unlikely that metacercarial infections are accidental in Palaemon macrodactylus. Rather, the infections would be the consequence of this genus having host specificities ranging between stenoxenous (phylogenetically related hosts) and euryxenous (ecologically related hosts). Also, the role of $P$. macrodactylus as a second intermediate host in the life cycle of Odhneria spp. would increase the likelihood that this helminth successfully completes its life cycle in the studied habitats. Odhneria spp. has been previously reported as metacercaria larva in the hemocoel and muscle of the grapsid crabs Neohelice granulata (Dana, 1851) and Cyrtograpus angulatus Dana, 1851 (Alda et al. 2011) and as adults of Odhneria odhneri Travassos, 1921, in the intestines of Olrog's Gull Larus atlanticus Olrog, 1958, from the Bahía Blanca estuary (La Sala et al. 2009). Palaemonid shrimp are preyed upon by Kelp gulls Larus dominicanus Lichtenstein, 1823 (Petracci et al. 2004), and by Olrog's gulls (L. F. La Sala pers. comm.) in the Bahía Blanca estuary; therefore, P. macrodactylus most probably serves as an intermediate host for the trophic transmission of helminth parasites to their final vertebrate hosts.

The morphological characteristics of the barnacles reported in the present work agree with those of the introduced striped barnacle Balanus amphitrite. This species has been previously reported as a fouling organism in Argentina (Elías \& Vallarino 2001, Spivak 2003).

In marine invasions, larval stages introduced via ballast water lack parasites that can infect adult stages (Lafferty \& Kuris 1996). During a parasitological survey conducted on $>50$ individuals of Palaemon macrodactylus from the Mar del Plata area between 2004 and 2005, no helminths were found in this species (S. R. Martorelli pers. comm.). These early negative parasitological results support the hypothesis that $P$. macrodactylus arrived in Argentina as helminth-free larvae and then acquired a role as a suitable intermediate host at least in the Bahía Blanca estuary, where this species seems to play a role in the trophic transmission of larval stages of microphallids, such as Odhneria spp., to their definitive hosts.

In our study, indirect evidence of bacterial infections, such as melanized cuticular lesions, were observed in some individuals. The cause of these lesions could not be determined; however, they were possibly associated with bacterial infections, viral infections, or healing of physical injuries (Lightner 1996, Noga et al. 2000).

The presence of white spots on the cuticular tissue could be due to its abnormal development leading to tissue thinning and calcium deposition. These lesions were similar to those observed in WSSVinfected Artemesia longinaris Bate, 1888 and Palae- 
mon macrodactylus (Martorelli et al. 2010). Despite this, in our study, the presence of cuticular lesions correlated very poorly $(0.05 \%)$ with infection by WSSV as evidenced using PCR.

Other pathogens, such as bacteria, can cause similar lesions in the carapace (e.g. bacterial white spot syndrome) (Wang et al. 2000), thus explaining the high rate of white spot-positive individuals that tested negative for WSSV through PCR.

The present study is the second report of WSSVinfected shrimp in the Bahía Blanca estuary, thus adding relevant data about the epidemiology of this virus (Martorelli et al. 2010). According to Martorelli et al. (2010), WSSV may have been introduced in Argentina by WSSV-infected Palaemon macrodactylus, some vector carried in ballast water, some infected crustaceans carried by natural currents from Brazil, or through infected seafood imported from other countries.

Our results suggest that WSSV, also present in Artemesia longinaris and Cyrtograpsus angulatus (Martorelli et al. 2010), is spreading in the crustacean populations of the Argentine Sea.

Acknowledgements. We thank G. Kopprio for collecting the prawn from the Río Negro estuary and F. Cardillo and N. Bonel for assisting with the collection of shrimp samples. This work was partially funded by a research grant from the Agencia Nacional de Promoción Científica y Técnica (PICT $34412 / 05)$.

\section{LITERATURE CITED}

Alda P, La Sala LF, Marcotegui P, Martorelli SR (2011) Parasites and epibionts of grapsid crabs in Bahía Blanca estuary, Argentina. Crustaceana 84:559-571

Buckworth R (1979) Aspects of the population dynamics of Palaemon macrodactylus (Decapoda: Palaemonidae) in Lake Mannering, NSW, and in the laboratory. MSc Thesis, University of New South Wales, Sydney

d'Udekem d'Acoz C, Faasse M, Dumoulin E, De Blauwe H (2005) Occurrence of the Asian shrimp, Palaemon macrodactylus Rathbun, 1902, in the Southern Bight of the North Sea, with a key to the Palaemonidae of northwest Europe (Crustacea, Decapoda, Caridea). Ned Faunist Meded 22:95-111

Elder N, Fuller P (2012) Palaemon macrodactylus. USGS Nonindigenous Aquatic Species Database, Gainesville, FL. http://nas.er.usgs.gov/queries/factsheet.aspx?Species ID=1206 Revision Date: 1/11/2011

Elías R, Vallarino EA (2001) The introduced barnacle Balanus glandula (Darwin) in the Mar del Plata port as a structuring species in the intertidal community. Invest Mar 29:37-46

González-Ortegón E, Cuesta JA (2006) An illustrated key to species of Palaemon and Palaemonetes (Crustacea: Decapoda: Caridea) from European waters, including the alien species Palaemon macrodactylus. J Mar Biol
Assoc UK 86:93-102

González-Ortegón E, Cuesta JA, Schubart CD (2007) First report of the oriental shrimp Palaemon macrodactylus Rathbun, 1902 (Decapoda, Caridea, Palaemonidae) from German waters. Helgol Mar Res 61:67-69

Hierro JL, Maron JL, Callaway RM (2005) A biogeographical approach to plant invasions: the importance of studying exotics in their introduced and native range. $\mathrm{J}$ Ecol 93:5-15

$>$ La Sala LF, Martorelli SR, Alda P, Marcotegui P (2009) Some digeneans from Olrog's Gull Larus atlanticus Olrog, 1958 (Aves: Laridae) from the Bahía Blanca Estuary, Argentina. Comp Parasitol 76:113-116

Lafferty KD, Kuris AM (1996) Biological control of marine pests. Ecology 77:1989-2000

Lightner DV (1996) A handbook of shrimp pathology and diagnostic procedures for diseases of cultured penaeid shrimp. World Aquaculture Society, Baton Rouge, LA

Martorelli SR, Overstreet RM, Jovonovich JA (2010) First report of viral pathogens WSSV and IHHNV in argentine crustaceans. Bull Mar Sci 86:117-131

> Newman WA (1963) On the introduction of an edible oriental shrimp (Caridea, Palaemonidae) to San Francisco Bay. Crustaceana 5:119-132

Noga EJ, Smolowitz R, Khoo LH (2000) Pathology of shell disease in the blue crab, Callinectes sapidus Rathbun, (Decapoda: Portunidae). J Fish Dis 23:389-399

Petracci P, La Sala L, Aguerre G, Perez C, Acosta N, Sotelo M, Pamparana C (2004) Dieta de la gaviota cocinera (Larus dominicanus) durante el periodo reproductivo en el estuario de Bahia Blanca, Buenos Aires, Argentina. Hornero 19:23-28

Rathbun MJ (1902) Japanese stalk-eyed crustaceans. Proc US Natl Mus 26:23-55

Spivak ED (2003) Los cirripedios litorales (Cirripedia, Thoracica, Balanomorpha) de la región del Río de la Plata y las costas marinas adyacentes. In: Penchaszadeh (ed) Especies animales bentónicas introducidas, actual o potencialmente invasoras en el sistema del Río de la Plata y la región costera oceánica aledaña del Uruguay y de la Argentina. Proyecto PNUD/GEF RLA/99/G31, Buenos Aires, p 229-283

Spivak ED, Boschi EE, Martorelli SR (2006). Presence of Palaemon macrodactylus Rathbun 1902 (Crustacea: Decapoda: Caridea: Palaemonidae) in Mar del Plata harbor, Argentina: first record from southwestern Atlantic waters. Biol Invasions 8:673-676

Stunkard HW (1979) The morphology, life-history, and taxonomic relations of Odhneria odhneri Travassos, 1921 (Digenea: Microphallidae). Biol Bull 156:234-245

- Torchin ME, Lafferty KD, Kuris AM (2001) Release from parasites as natural enemies: increased performance of a globally introduced marine crab. Biol Invasions 3:333-345

Torchin ME, Mitchell ChE (2004) Parasites, pathogens, and invasions by plants and animals. Front Ecol Environ 2: 183-190

Wang YG, Lee KL, Najiah M, Shariff M, Hassan MD (2000) A new bacterial white spot syndrome (BWSS) in cultured tiger shrimp Penaeus monodon and its comparison with white spot syndrome (WSS) caused by virus. Dis Aquat Org 41:9-18

- Wasson K, Zabin ChJ, Bedinger L, Diaz MC, Pearse JS (2001) Biological invasions of estuaries without international shipping: the importance of intraregional transport. Biol Conserv 102:143-153 